\title{
Assessment of quality of life of patients with leprosy reactional states treated in a dermatology reference center
}

\author{
Avaliação da qualidade de vida de pacientes em surto reacional de \\ hanseníase tratados em centro de referência
}

\author{
Marina Dias Costa ${ }^{1}$ \\ Rosane Dias Costa ${ }^{1}$ \\ Ana Maria Duarte Dias Costa ${ }^{4}$
}

\author{
Fábio de Souza Terra² \\ Sandra Lyon $^{3}$ \\ Carlos Maurício de Figueiredo Antunes ${ }^{5}$
}

\begin{abstract}
BACKGROUND: Disabilities and deformities resulting from reactive outbreaks of leprosy can cause many problems for the patients, interfering with their quality of life.

ОвJестіves: To assess the quality of life of patients with leprosy reactional states identified at the Reference Center in Belo Horizonte - MG. METHODS: This was an epidemiological cross-sectional descriptive and analytical study, involving 120 patients in treatment for leprosy reactional states, from December 2007 to March 2008, held at the Dermatology outpatients clinic of the Hospital Eduardo de Menezes from FHEMIG, BH. We used two instruments for the socio-demographic, economic and clinical variables and a generic instrument WHOQOL WHO. The data were tabulated in SPSS and analyzed using the mean score with the application of statistical tests $(\mathrm{p}<0.05)$.

RESULTS: We found that the median age of the patients was 48 years, most were males, married, from cities around BH, with incomplete elementary school, retired or pensioner, and with a family income of two minimum wages. Most of them reported that the disease interfered a great deal with their professional activities and leisure. In the assessment of QoL, the lowest rating was observed in the physical domain and the highest was observed in the psychological and social relations. The internal consistency of WHOQOL-bref was acceptable to the facets and domains.
\end{abstract}

ConCLUSIONS: Leprosy causes suffering that goes beyond the pain and discomfort strictly related to the physical damage, with great social and psychological impact.

Keywords: Leprosy; Leprosy, borderline; Leprosy, lepromatous; Quality of life; Sickness impact profile

Resumo: FunDAmENTOS: As incapacidades e deformidades decorrentes dos surtos reacionais de hanseníase podem acarretar inúmeros problemas aos pacientes, interferindo na qualidade de vida.

OвJETivos: Avaliar a qualidade de vida de pacientes portadores de hanseníase em estado reacional identificados em centro de referência de Belo Horizonte, MG.

MÉToDos: Trata-se de um estudo epidemiológico transversal, descritivo e analítico, envolvendo 120 pacientes em tratamento de surto reacional de hanseníase, no período de dezembro de 2007 a março de 2008, realizado no ambulatório de dermatologia do Hospital Eduardo de Menezes da Fhemig. Foram utilizados dois instrumentos referentes às variáveis sociodemográficas, econômicas e clínicas e o instrumento genérico WHOQOL-bref da OMS. Os dados foram tabulados no SPSS e analisados por meio do escore médio com aplicação de testes estatísticos $(\mathrm{p}<0,05)$.

Resultados: Constatou-se que a mediana da idade dos pacientes estudados foi de 48 anos, sendo a maioria deles do sexo masculino, casada, de cidades circunvizinhas a BH, com primeiro grau incompleto, aposentada ou gozando de licença saúde e com renda familiar de um a dois salários mínimos vigentes. A maioria deles relatou que a doença interferiu muito nas atividades profissionais e de lazer. Na avaliação da QV, o índice mais baixo foi observado no domínio físico e os mais altos foram observados nos domínios psicológico e das relações sociais. A consistência interna do WHOQOL-bref foi aceitável para as facetas e domínios.

Conclusões: A hanseníase causa sofrimento que ultrapassa a dor e o mal-estar estritamente vinculados ao prejuízo físico, com grande impacto social e psicológico.

Palavras-chave: Hanseníase; Hanseníase dimorfa; Hanseníase virchowiana; Perfil de impacto da doença; Qualidade de vida

Received on 05.03.2010.

Approved by the Advisory Board and accepted for publication on 27.02.11

* Work perfomed on the Outpatients Clinic of the Hospital Eduardo de Menezes - Fundação Hospitalar do Estado de Minas Gerais (FHEMIG) - Belo Horizonte (MG), Brasil.

Conflict of interest: None / Conflito de interesse: Nenbum

Financial funding: None / Suporte financeiro: Nenhum

Master in Internal Medicine - Dermatologist, Physician and Teacher at the Centro de Medicina Especializada, Pesquisa e Ensino (CEMEPEMG) - Belo Horizonte (MG), Brasil.

PhD in Sciences - Teacher at the Nursing Course of the Universidade Federal de Alfenas (UNIFAL) - Alfenas (MG), Brasil.

PhD in Dermatology - Dermatologist, Physician, Teacher and Coordinator of the Medical Residency in Dermatology of the Hospital Eduardo de Menezes Fundação Hospitalar do Estado de Minas Gerais (FHEMIG) - Belo Horizonte (MG), Brasil.

PhD in Pharmacology - Full Professor of the Medicine and Dentistry course of the Universidade José do Rosário Vellano (UNIFENAS) - Alfenas (MG), Brasil.

PhD in Epidemiology - Full Professor of the Instituto de Ciências Biológicas of the Universidade Federal de Minas Gerais (UFMG) - Belo Horizonte (MG), Brasil.

CC2012 by Anais Brasileiros de Dermatologia 


\section{INTRODUCTION}

Nowadays health is regarded in a broad, complex and positive concept that relies on social and personnel resources, and not only on the individuals' physical capacity or biologic conditions.

Amongst the infecto-contagious diseases that still remain a public health problem in the country, Leprosy stands out, and Brazil is the second most endemic in the world. ${ }^{1}$

Leprosy is a chronic, granulomatous, infectocontagious disease caused by the Mycobacterium leprae and it is mainly manifested by dermato-neurologic signs and symptoms. Its transmission happens from person to person by close and prolonged contact with patients with the bacillary forms without treatment. ${ }^{1.5}$

The greatest morbidity is associated to reactional states and neural involvement, which can cause permanent physical incapacities and deformities, leading to rejection behaviours and discrimination against the patient, with eventual exclusion from society. ${ }^{6}$

The endemicity status, associated with low socio-economic and environmental conditions, the severity of the disease, the occurrence of clinical parallel conditions or complications and the amount of medication required to alleviate the symptoms, made worse by the high percentage of patients with incapacities, can significantly interfere with the quality of life (QoL). ${ }^{7}$

Therefore, the combination of social prejudice, functional limitation and human suffering that are associated with leprosy explain why the disease is feared more than others, even fatal diseases. ${ }^{8}$

The preoccupation with the QoL of the of individuals with chronic health conditions has been a constant fact in the works developed by the research group NUCRN (Núcleo de Convivência em Situações Crônicas de Saúde - Living with Chronic Health Situations Nucleus), whose researchers believe that even when it is not possible to change the course of life and the disease, it is possible that people with these conditions remain healthy. Results from this research group studies have shown that healthy ways to deal with chronic conditions can be learned by means of an educational process where, mostly, the sharing of experiences in groups is exercised., 10

The measuring instruments of QoL related to health tend to maintain the multidimensional character and yet analyse the overall perception of the QoL, although the emphasis is usually on the symptoms, incapacities or limitations caused by the malady. ${ }^{11}$

In the context of the quality of life of patients with leprosy, it is worth mentioning that the stigma caused by this disease affects mental health and the
QoL, although few studies have researched the issue in this population. ${ }^{12}$

In view of the issues discussed above, we decided to perform this study with the objective of assessing the quality of life of patients with leprosy in reactional states identified at the Centro de Referência de Belo Horizonte - MG, aiming at objective measures to minimize the problem for people with this disease, which is aggravated by the fact that it is historically associated with stigmas, which perpetuates the idea of a mutilating and incurable condition, leading to attitudes of rejection and discrimination.

\section{MATERIAL AND METHODS}

This is an epidemiologic, descriptive, cross-sectional study with a quantitative approach. The sample was intentionally composed of 120 patients under treatment of reactional outbreak of leprosy at the Centro de Referência em Dermatologia Sanitária. The data collection went under way after approval by the Research Ethics Committee from the Hospital Eduardo de Menezes of the Fundação Hospitalar do Estado de Minas Gerais (FHEMIG), where the research was performed, located in the city of Belo Horizonte-MG. The participants were also asked to sign the Free and Explained Consent Form.

For the data collection a questionnaire was used composed of structured and semi-structured questions asking about socio-economic aspects and characteristics of the study participants, as well as information regarding the disease. The data related to quality of life were collected using the instrument WHOQOL-bref, tested and validated in various cultures, under the coordination of the World Health Organization Quality of Life Group (WHOQOL Group) from the World Health Organization (WHO). ${ }^{13}$ This instrument is composed of 26 questions, where two are general questions and the remaining 24 encompassing four domains: physical, psychological, social relations and environment. ${ }^{14}$ This facets and their respective domains are exposed on chart 1.

The questions from WHOQOL-bref have four ratings of answers: intensity, capacity, frequency and evaluation, all graded in five levels ( 1 to 5$).^{15,16}$

For the data analyses the software Statistical Package for Social Science (SPSS) version 12.0 was used, which is the model recommended and validated for the quality of life instrument (WHOQOL-bref), which allows for the gathering of the scores. The average score of each one of the facets was calculated and subsequently the average score of each one of the 4 domains, as well as the global perception of QoL and health, and the calculation of the average and median.

For the comparison of the domains 'scores and 
ChART 1: Domains and facets of the WHOQOL-bref

\section{Physical Domain}

Pain and discomfort

Dependency on medication or treatment

Energy and fatigue

Sleep and rest

Mobility

Daily activities

Work capacity

\section{Psychology Domain}

Positive feelings

Spirituality/religion/beliefs

Thinking, learning, memory and concentration

Negative feelings

Corporal image and appearance

Self-esteem

\section{Social Relations Domain}

Personal relations

Sexual activity

Social support

\author{
Environment Domain \\ Physical safety and protection \\ Opportunities for information \\ Physical and home environment \\ Health and social care \\ Finantial resurces \\ Transport \\ Participatin and leisure activities
}

the global perception of QoL and health with the variables the Mann-Whitney test (comparison of two groups) or the Kruskall-Wallis test (comparison of three or more groups) was used. We chose the nonparametric tests due to the asymmetric characteristic of the quality of life ratings. ${ }^{17}$

For the correlation of the domains 'scores and global perception of QoL and health and age (continuous) the Spearman correlation coefficient was used. This is a non-parametric correlation coefficient, since the QoL ratings have an asymmetric characteristic. ${ }^{17}$

The Pearson's chi-square test or the Fisher Exact Test was used for the comparison of categorical facts associated with the clinical form (borderline and lepromatous).

The evaluation of the internal consistency of the WHOQOL-bref, which means the correlation and homogeneity amongst the instrument items in each of its domains, was performed using the Cronbach Alpha Coefficient.

For all the statistical tests the level of significance of $5 \%$ was considered, or the data was statistically significant for $\mathrm{p}<0,05$.

\section{RESULTS}

The results showed that most patients were male $(65,0 \%)$, married $(65,0 \%)$, retired/pensioner $(53,3 \%)$, living in cities around $\mathrm{BH}(58,3 \%)$, completed elementary school $(74,2 \%)$, with family income from one to two minimum wages $(70,0 \%)$, aged around 47,0 years, with borderline clinical form $(56,7 \%)$, duration of the leprosy and treatment of five years or more $(37,9 \%$ e $33,3 \%$, respectively), without co-morbidities $(62,5 \%)$, no dependant on help $(65,5 \%)$.

When analysing the QoL of the patients in rela- tion to the WHOQOL-bref domains a worse quality of life on the physical domain was observed (median of $46,4)$, followed by environment and global perception of QoL and health (median of 50, 0), psychological domain and social relations (median of 58, 3) (Table 1).

When comparing sex in relation to quality of life there was no statistically significant difference in any of the domains studied $(p>0,05)$ and, when compared to age, again there were no statistically significant differences in this study $(\mathrm{p}>0,05)$.

When analysing quality of life against marital status there was a statistically significant difference only for the social relations domain $(p=0,001)$, with a better quality of life among the married patients $(66$, 7) followed by the widowed $(58,3)$ and, last, the single ones (50) (Table 2).

In terms of sexual life satisfaction it was observed on the present study that there was a higher frequency of patients who reported being "neither satisfied, nor dissatisfied" $(37,5 \%)$.

In terms of city of residence there was a statistically significant difference only for the environment domain $(p=0,033)$ (Table 3). In this domain, a better quality of life was observed for the group of patients living in Belo Horizonte. It is important to emphasize that most of the patients in this study $(74,2 \%)$ is satisfied with their access to Health Services.

A surprising fact found on the present study when comparing the quality of life with the different levels of schooling was the absence of a statistically significant difference $(p>0,05)$, although the ratings of the domains and the global perception of QoL and health on those with some level of schooling were higher.

When the quality of life was compared with the occupation variable there was a statistically significant 
TABLE 1: Descriptive statistics of global perception of QoL and health and the ratings domains of the WHOQOLbref grading of the 120 leprosy patients in Reactional Outbreak seen at the Sanitary Dermatology Reference Center of the Hospital Eduardo de Menezes of the Fundação Hospitalar do Estado de Minas Gerais - FHEMIG, Belo Horizonte, December 2007 to March 2008

\begin{tabular}{llllll}
\hline & \multicolumn{5}{c}{ Descriptive Statistics } \\
\cline { 2 - 6 } WHOQOL-bref & Average & Median & Standard Deviation & Minimum & Maximum \\
\hline Global Perception QoL and Health & 50,3 & 50,0 & 15,7 & 12,5 & 75,0 \\
Physical Domain & 48,2 & 46,4 & 15,5 & 10,7 & 92,9 \\
Psychological Domain & 58,6 & 58,3 & 14,3 & 8,3 & 87,5 \\
Social Relations Domain & 61,7 & 58,3 & 16,4 & 16,7 & 100,0 \\
Environment Domain & 53 & 50 & 10,8 & 15,6 & 78,1 \\
\hline
\end{tabular}

difference ( $\mathrm{p}$-values $\mathrm{p}<0,05)$ for the domains physical, psychological and environment, and in a limitrophe form ( $\mathrm{p}$-value $\mathrm{p}=0,055$ ) for the global perception of QoL and health (Table 4). In all aspects a better quality of life was observed on the group "home duties" and the worse quality of life on the group "retired/pensioner".

The present study still showed that there was a statistically significant difference between occupation and interference of the disease with professional activities $(p<0,001)$, and the percentage of patients that believe that the disease interferes a lot or completely with professional activities was higher amongst the retired or pensioners when compared to the other occupational groups. It is also important to mention that there was a worse quality of life for those who reported high interference of the disease with professional activities. Worth mentioning is the fact that, of the studied sample, most patients (approximately $50 \%)$ reported that they were dissatisfied with their capacity for work.

There was also a statistically significant difference between interference with professional activities and family income $(\mathrm{p}<0,001)$, and the percentage of patients that believed that the disease interfered a lot or completely with these activities was higher amongst

TABLE 2: Descriptive Statistics with presentation of the average, median and standard deviation and comparison of the ratings of each domain and of the global perception of QoL and health of the WHOQOL-bref grading by marital status of the 120 leprosy patients in Reactional Outbreak seen at the Sanitary Dermatology Reference Center of the Hospital Eduardo de Menezes of the Fundação Hospitalar do Estado de Minas Gerais - FHEMIG, Belo Horizonte, December 2007 to March 2008

\begin{tabular}{|c|c|c|c|c|c|c|}
\hline $\begin{array}{l}\text { Marital } \\
\text { Status }\end{array}$ & Statistics & $\begin{array}{l}\text { Global Perception } \\
\text { QoL and Health }\end{array}$ & $\begin{array}{l}\text { Physical } \\
\text { Domain }\end{array}$ & $\begin{array}{l}\text { Psychological } \\
\text { Domain }\end{array}$ & $\begin{array}{l}\text { Social Relations } \\
\text { Domain }\end{array}$ & $\begin{array}{l}\text { Environment } \\
\text { Domain }\end{array}$ \\
\hline \multirow{5}{*}{ Married } & Average & 51,0 & 46,8 & 59,4 & 65,4 & 52,8 \\
\hline & Median & 50,0 & 46,4 & 58,3 & 66,7 & 50,0 \\
\hline & Standard Deviation & 14,8 & 14,7 & 11,5 & 13,4 & 9,6 \\
\hline & Minimum & 12,5 & 10,7 & 29,2 & 16,7 & 28,1 \\
\hline & Maximum & 75,0 & 78,6 & 83,3 & 100,0 & 78,1 \\
\hline \multirow{5}{*}{ Single } & Average & 47,7 & 50,3 & 56,0 & 53,4 & 52,1 \\
\hline & Median & 50,0 & 48,2 & 58,3 & 50,0 & 50,0 \\
\hline & Standard Deviation & 17,2 & 15,2 & 18,9 & 20,1 & 13,2 \\
\hline & Minimum & 12,5 & 21,4 & 8,3 & 16,7 & 15,6 \\
\hline & Maximum & 75,0 & 78,6 & 79,2 & 100,0 & 78,1 \\
\hline \multirow{5}{*}{ Widow } & Average & 51,4 & 50,4 & 57,4 & 60,2 & 56,6 \\
\hline & Median & 37,5 & 46,4 & 54,2 & 58,3 & 50,0 \\
\hline & Standard Deviation & 17,1 & 22,0 & 16,0 & 17,6 & 12,5 \\
\hline & Minimum & 37,5 & 28,6 & 29,2 & 41,7 & 43,8 \\
\hline & Maximum & 75,0 & 92,9 & 83,3 & 100,0 & 78,1 \\
\hline P-value* & & 0,725 & 0,623 & 0,917 & 0,001 & 0,752 \\
\hline
\end{tabular}


TABLE 3: Descriptive statistics with presentation of the average, median and standard deviation and comparison of the ratings of each domain and the global perception of the quality of life and health with the WHOQOL-

bref grading by city of residence of the 120 leprosy patients in Reactional Outbreak seen at the Sanitary Dermatology Reference Center of the Hospital Eduardo de Menezes of the Fundação Hospitalar do Estado de Minas Gerais - FHEMIG, Belo Horizonte, December 2007 to March 2008

\begin{tabular}{|c|c|c|c|c|c|c|}
\hline City & Statistics & $\begin{array}{l}\text { Global Perception } \\
\text { QoL and Health }\end{array}$ & $\begin{array}{l}\text { Physical } \\
\text { Domain }\end{array}$ & $\begin{array}{l}\text { Psychological } \\
\text { Domain }\end{array}$ & $\begin{array}{l}\text { Social Relations } \\
\text { Domain }\end{array}$ & $\begin{array}{l}\text { Environment } \\
\text { Domain }\end{array}$ \\
\hline \multirow{5}{*}{$\mathrm{BH}$} & Average & 48,5 & 48,0 & 58,9 & 60,5 & 54,8 \\
\hline & Median & 50,0 & 46,4 & 58,3 & 58,3 & 53,1 \\
\hline & Standard Deviation & 15,7 & 14,2 & 14,8 & 16,8 & 10,8 \\
\hline & Minimum & 12,5 & 21,4 & 12,5 & 16,7 & 15,6 \\
\hline & Maximum & 75,0 & 78,6 & 79,2 & 100,0 & 78,1 \\
\hline \multirow{5}{*}{$\begin{array}{l}\text { Neighb } \\
\text { Cities }\end{array}$} & Average & 51,6 & 48,4 & 58,3 & 62,6 & 51,7 \\
\hline & Median & 50,0 & 46,4 & 58,3 & 66,7 & 50,0 \\
\hline & Standard Deviation & 15,6 & 16,5 & 14,0 & 16,2 & 10,7 \\
\hline & Minimum & 12,5 & 10,7 & 8,3 & 16,7 & 28,1 \\
\hline & Maximum & 75,0 & 92,9 & 87,5 & 100,0 & 78,1 \\
\hline P-value* & & 0,292 & 0,930 & 0,628 & 0,423 & 0,033 \\
\hline
\end{tabular}

*Mann-Whitney Test

those with a family income of less than two minimum wages.

When comparing quality of life with family income, a statistically significant difference was observed for the physical $(p=0,001)$, psychological $(p=0,026)$, environmental $(p=0,025)$ and global perception of QoL and health $(\mathrm{p}=0,027)$ domains (Table 5). In any case, a better quality of life was observed in the group with three or more minimum wages. It is important to mention that, when asked the participants if they had enough money for their needs the majority, 65, 9\%, answered "nothing" and "very little".

In this study, considering that there was a high interference with leisure for most of the participants

TABLE 4: Descriptive statistics with presentation of the average, median and standard deviation and comparison of the ratings of each domain and the global perception of the quality of life and health with the WHOQOL-

bref grading by occupation of the 120 leprosy patients in Reactional Outbreak seen at the Sanitary Dermatology Reference Center of the Hospital Eduardo de Menezes of the Fundação Hospitalar do Estado de Minas Gerais - FHEMIG, Belo Horizonte, December 2007 to March 2008

\begin{tabular}{|c|c|c|c|c|c|c|}
\hline Ocuppation & Statistics & $\begin{array}{l}\text { Global Perception } \\
\text { QoL and Health }\end{array}$ & $\begin{array}{l}\text { Physical } \\
\text { Domain }\end{array}$ & $\begin{array}{l}\text { Psychological } \\
\text { Domain }\end{array}$ & $\begin{array}{l}\text { Social Relations } \\
\text { Domain }\end{array}$ & $\begin{array}{l}\text { Environment } \\
\text { Domain }\end{array}$ \\
\hline \multirow{5}{*}{$\begin{array}{l}\text { Retired/ } \\
\text { pensioner }\end{array}$} & Average & 47,3 & 43,2 & 56,4 & 59,8 & 51,5 \\
\hline & Median & 50,0 & 42,9 & 54,2 & 58,3 & 50,0 \\
\hline & Standard Deviation & 12,5 & 12,9 & 10,3 & 14,7 & 9,4 \\
\hline & Minimum & 12,5 & 10,7 & 29,2 & 16,7 & 28,1 \\
\hline & Maximum & 75,0 & 75,0 & 79,2 & 100,0 & 78,1 \\
\hline \multirow{5}{*}{ Home duties } & Average & 56,3 & 53,6 & 62,5 & 68,8 & 60,2 \\
\hline & Median & 56,3 & 55,4 & 64,6 & 75,0 & 60,9 \\
\hline & Standard Deviation & 11,6 & 12,4 & 12,0 & 13,2 & 6,6 \\
\hline & Minimum & 37,5 & 35,7 & 37,5 & 41,7 & 50,0 \\
\hline & Maximum & 75,0 & 71,4 & 75,0 & 83,3 & 71,9 \\
\hline \multirow{5}{*}{ Others } & Average & 53,4 & 54,0 & 60,9 & 63,2 & 53,8 \\
\hline & Median & 50,0 & 53,6 & 62,5 & 66,7 & 53,1 \\
\hline & Standard Deviation & 19,1 & 17,0 & 18,4 & 18,7 & 12,6 \\
\hline & Minimum & 12,5 & 10,7 & 8,3 & 16,7 & 15,6 \\
\hline & Maximum & 75,0 & 92,9 & 87,5 & 100,0 & 78,1 \\
\hline P-value* & & 0,055 & 0,000 & 0,008 & 0,085 & 0,020 \\
\hline
\end{tabular}


TABLE 5: Descriptive statistics with presentation of the average, median and standard deviation and comparison of the ratings of each domain and the global perception of the quality of life and health with the WHOQOL-

bref grading by family income of the 120 leprosy patients in Reactional Outbreak seen at the Sanitary Dermatology Reference Center of the Hospital Eduardo de Menezes of the Fundação Hospitalar do Estado de Minas Gerais - FHEMIG, Belo Horizonte, December 2007 to March 2008

\begin{tabular}{|c|c|c|c|c|c|c|}
\hline Income & Statistics & $\begin{array}{l}\text { Global Perception } \\
\text { QoL and Health }\end{array}$ & $\begin{array}{l}\text { Physical } \\
\text { Domain }\end{array}$ & $\begin{array}{l}\text { Psychological } \\
\text { Domain }\end{array}$ & $\begin{array}{l}\text { Social Relations } \\
\text { Domain }\end{array}$ & $\begin{array}{l}\text { Environment } \\
\text { Domain }\end{array}$ \\
\hline \multirow{5}{*}{$\begin{array}{l}\text { Less than } 2 \\
\text { minimum } \\
\text { wages }\end{array}$} & Average & 48,5 & 45,7 & 57,4 & 62,0 & 52,0 \\
\hline & Median & 50,0 & 42,9 & 58,3 & 58,3 & 50,0 \\
\hline & Standard Deviation & 15,1 & 15,4 & 13,5 & 16,0 & 10,3 \\
\hline & Minimum & 12,5 & 10,7 & 8,3 & 16,7 & 28,1 \\
\hline & Maximum & 75,0 & 92,9 & 83,3 & 100,0 & 78,1 \\
\hline \multirow{5}{*}{$\begin{array}{l}3 \text { or more } \\
\text { wages }\end{array}$} & Average & 55,6 & 55,6 & 62,1 & 61,0 & 55,8 \\
\hline & Median & 50,0 & 53,6 & 66,7 & 66,7 & 56,3 \\
\hline & Standard Deviation & 16,4 & 13,6 & 16,1 & 17,7 & 11,9 \\
\hline & Minimum & 25,0 & 28,6 & 16,7 & 16,7 & 15,6 \\
\hline & Maximum & 75,0 & 78,6 & 87,5 & 83,3 & 78,1 \\
\hline P-value* & & 0,027 & 0,001 & 0,026 & 0,817 & 0,025 \\
\hline
\end{tabular}

*Mann-Whitney Test

$(50,5 \%)$, there was a statistically significant difference in all the domains of quality of life $(\mathrm{p}<0,05)$ (Table 6$)$. In any case, the best quality of life was observed in patients that reported that the disease did not interfere with their leisure activities and the worst in those who reported high interference. In terms of opportunity for leisure activities, $43,3 \%$ of the patients believed they had very few opportunities.

It was observed that the pain prevented "a lot" and "extremely" most patients (50\%) from carrying out their usual activities. When correlating the presence or not of pain with quality of life, a statistically significant difference was observed in all the domains of QoL $(p<0,05)$, in other words, a better quality of life was reported by those who had no pain (Table 7).

When comparing the quality of life of each domains with the clinical forms of leprosy, there was no statistically significant difference $(p>0,05)$, and the same happened when comparing the clinical forms with the clinical, socio-demographic, and economic characteristics of the patients studied $(p>0,05)$.

In terms of the level of physical incapacity evaluated at the moment of admission, $16 \%$ of the patients studied presented with level $0,61 \%$ level 1 and $23 \%$ level 2 . The domains of the ratings of the WHOQOL-bref, except for social relations and global perception of QoL and health, showed statistically significant difference for level of incapacity, $(p<0,05)$ (Table 8 ), and $22,5 \%$ of the participants presented with physical alterations and $82,5 \%$ with sensory alterations. In general, the higher the level of incapacity the worst the quality of life.

It could be observed that of the patients stu- died, $85,9 \%$, reported negative feelings like bad mood, desperation, anxiety and depression, with the following intensities: always $(7,5 \%)$, very frequently (5\%), frequently (24,2\%) and sometimes (49,2\%). At the same time, in terms of acceptance of the clinical appearance, $50 \%$ of the participants reported being "more or less" satisfied with their clinical appearance.

In order to evaluate the Internal Consistency of the WHOQOL-bref the "Cronbach Alpha Coefficient" was used. The referred instrument used on the present study showed alpha values higher than 0,60 , and the total (26 facets) had a value of 0,91 , and the physical and psychological domains 0,83 e 0,81 , respectively.

\section{DISCUSSION}

In terms of sex, both men and women have their social roles threatened due to the leprosy, leading to psychological suffering. Besides, in men it represents a threat to the role of provider of family assistance, with decrease of the productive capacity and loss of sexual potency, and in women a feeling of deprivation of their ability to perform their chores, both within the family environment (domestic administration and care of the children) and outside (work). ${ }^{18}$

On the literature it was observed that the older the patients the higher the difficulties found in socializing, both due to the history of prejudice linked to the disease and the threats and losses accumulated along the way that interfere with the patient's daily life, leaving an indelible mark on its biography, to which the disease is associated. ${ }^{19,20}$ This data is discor- 
TABLE 6: Descriptive statistics with presentation of the average, median and standard deviation and comparison of the ratings of each domain and the global perception of the quality of life and health with the WHOQOLbref grading by interference with leisure activities of the 120 leprosy patients in Reactional Outbreak seen at the Sanitary Dermatology Reference Center of the Hospital Eduardo de Menezes of the Fundação Hospitalar do Estado de Minas Gerais - FHEMIG, Belo Horizonte, December 2007 to March 2008

\begin{tabular}{|c|c|c|c|c|c|c|}
\hline $\begin{array}{l}\text { Interference } \\
\text { with leisure } \\
\text { activities }\end{array}$ & Statistics & $\begin{array}{l}\text { Global Perception } \\
\text { QoL and Health }\end{array}$ & $\begin{array}{l}\text { Physical } \\
\text { Domain }\end{array}$ & $\begin{array}{l}\text { Psychological } \\
\text { Domain }\end{array}$ & $\begin{array}{l}\text { Social Relations } \\
\text { Domain }\end{array}$ & $\begin{array}{l}\text { Environment } \\
\text { Domain }\end{array}$ \\
\hline \multirow{5}{*}{ None } & Average & 60,7 & 63,8 & 67,6 & 68,2 & 58,8 \\
\hline & Median & 68,8 & 67,9 & 68,8 & 70,8 & 59,4 \\
\hline & Standard Deviation & 16,9 & 13,7 & 12,3 & 14,7 & 9,5 \\
\hline & Minimum & 25,0 & 35,7 & 37,5 & 33,3 & 43,8 \\
\hline & Maximum & 75,0 & 92,9 & 87,5 & 100,0 & 78,1 \\
\hline \multirow{5}{*}{ Very little } & Average & 58,0 & 55,1 & 65,5 & 66,1 & 56,0 \\
\hline & Median & 62,5 & 55,4 & 64,6 & 66,7 & 56,3 \\
\hline & Standard Deviation & 11,6 & 8,7 & 8,9 & 10,1 & 9,8 \\
\hline & Minimum & 37,5 & 35,7 & 50,0 & 41,7 & 37,5 \\
\hline & Maximum & 75,0 & 67,9 & 79,2 & 83,3 & 71,9 \\
\hline \multirow{5}{*}{ Little } & Average & 51,9 & 47,3 & 58,7 & 63,1 & 51,0 \\
\hline & Median & 50,0 & 46,4 & 58,3 & 62,5 & 50,0 \\
\hline & Standard Deviation & 12,1 & 12,1 & 9,1 & 16,5 & 7,9 \\
\hline & Minimum & 37,5 & 28,6 & 41,7 & 25,0 & 28,1 \\
\hline & Maximum & 75,0 & 78,6 & 83,3 & 100,0 & 71,9 \\
\hline \multirow{5}{*}{ A lot } & Average & 42,4 & 38,9 & 52,6 & 56,7 & 50,2 \\
\hline & Median & 37,5 & 39,3 & 54,2 & 58,3 & 50,0 \\
\hline & Standard Deviation & 12,3 & 11,3 & 14,3 & 17,2 & 11,7 \\
\hline & Minimum & 12,5 & 10,7 & 8,3 & 16,7 & 15,6 \\
\hline & Maximum & 75,0 & 64,3 & 79,2 & 100,0 & 78,1 \\
\hline P-value* & & $<0,001$ & $<0,001$ & $<0,001$ & 0,007 & 0,001 \\
\hline
\end{tabular}

*Kruskall-Wallis Test

dant with that of the present study, probably because of the small percentage of elderly people on the sample ( 21 patients).

It is worth mentioning that the worst quality of life was observed in patients with the longest duration of the disease and the treatment. Under this context the reactional episodes are many times chronic and relapsing and the severity of the leprosy is evaluated mostly by the incapacities it causes, by the psychosocial problems it leads to and by the long duration of the treatment. ${ }^{20}$

It is important to emphasize that the marital situation is a preponderant factor in terms of support to the patient, during the diagnosis and the treatment of leprosy. ${ }^{21}$ This fact was observed in this study, as the married group reported a better quality of life.

Researchers have observed that the alliance and the participation of the family are indispensable on the progress of the disease, as the patients with leprosy seek someone they trust and that can give them support. Some authors have reported that leprosy causes disturbances not only to the public life, but also to the affective and sexual life. ${ }^{18,21,22}$ In terms of sexual life satisfaction, it was observed that $37,5 \%$ of the patients reported being "neither satisfied, nor dissatisfied" on the present study.

On the environment domain, the best quality of life was observed in those living in Belo Horizonte. This can be justified by the better access to and better assistance offered by the reference services in Sanitary Dermatology in the city of Belo Horizonte-MG, to where the most complex cases are sent.

On the present study it was noted that higher ratings were given to the domains and global perception of QoL and health by those with some level of schooling, which could be justified by the small number of illiterate patients and those with secondary school and superior education, a total of only $26 \%$ of the participants, making it impossible to take any conclusion in this regard.

Another relevant fact is the high number of pensioners due to leprosy, without any lesion that could 
TABLE 7: Descriptive statistics with presentation of the average, median and standard deviation and comparison of the ratings of each domain and the global perception of the quality of life and health with the WHOQOLbref grading by presence of pain consequent to leprosy of the 120 leprosy patients in Reactional Outbreak seen at the Sanitary Dermatology Reference Center of the Hospital Eduardo de Menezes of the Fundação

Hospitalar do Estado de Minas Gerais - FHEMIG, Belo Horizonte, December 2007 to March 2008

\begin{tabular}{|c|c|c|c|c|c|c|}
\hline Pain & Statistics & $\begin{array}{l}\text { Global Perception } \\
\text { QoL and Health }\end{array}$ & $\begin{array}{l}\text { Physical } \\
\text { Domain }\end{array}$ & $\begin{array}{l}\text { Psychological } \\
\text { Domain }\end{array}$ & $\begin{array}{l}\text { Social Relations } \\
\text { Domain }\end{array}$ & $\begin{array}{l}\text { Environment } \\
\text { Domain }\end{array}$ \\
\hline \multirow{5}{*}{ No } & Average & 54,0 & 59,2 & 65,9 & 66,1 & 57,0 \\
\hline & Median & 50,0 & 60,7 & 66,7 & 66,7 & 56,3 \\
\hline & Standard Deviation & 16,6 & 13,0 & 11,5 & 17,3 & 10,5 \\
\hline & Minimum & 25,0 & 35,7 & 33,3 & 16,7 & 37,5 \\
\hline & Maximum & 75,0 & 78,6 & 87,5 & 100,0 & 78,1 \\
\hline \multirow{5}{*}{ Yes } & Average & 49,0 & 44,4 & 56,0 & 60,2 & 51,6 \\
\hline & Median & 50,0 & 42,9 & 54,2 & 58,3 & 50,0 \\
\hline & Standard Deviation & 15,2 & 14,5 & 14,4 & 15,9 & 10,6 \\
\hline & Minimum & 12,5 & 10,7 & 8,3 & 16,7 & 15,6 \\
\hline & Maximum & 75,0 & 92,9 & 83,3 & 100,0 & 78,1 \\
\hline P-value* & & 0,173 & $<0,001$ & $<0,001$ & 0,039 & 0,029 \\
\hline
\end{tabular}

*Mann-Whitney Test

decrease their physical capacity, where the leprosy patient is taken out of the workforce because of prejudice, without taking into consideration the human aspect and the use of the workforce, which in itself would be reason enough to proceed with the campaigns aiming at ending with the stigma of the disease forever. ${ }^{23}$

It is a consensus amongst some authors that leprosy is still responsible for leaving the workforce and isolation from social life and community participation, due to its incapacitating potential, keeping alive the stigma of the disease and compromising the quality of life. ${ }^{22,24-26}$ It is worth mentioning that, from the sample studied, most individuals reported being dissatisfied with their capacity to work.

In any case, the best quality of life was observed in the group with three or more minimum wages, which is confirmed on the literature when describing that the economic aspects influence the ways of facing health problems. ${ }^{27}$

Patients with leprosy in reactional outbreak report a decrease of leisure and social activities, leading to social isolation not only due to bothering pains but also by personal option. In this context, being a patient with leprosy has caused psychological suffering, and both men and women have their social roles threatened. ${ }^{18}$ On the present study it was observed that $43,3 \%$ of the patients thought they had "very little" opportunities for leisure activities.

The patients with leprosy reported that the disease cause them moderate pains all over the body, endangering the harmony of their lives, preventing them from working and performing physical tasks, imposing limitations to their activities, leading to serious changes to their lives, like decrease of leisure and social activities and causing isolation, which is corroborated by the present study, by observing that overall a better quality of life was seem in the patients who reported no pain. ${ }^{18}$

In terms of the clinical form it is important to emphasize that the multibacillary patients present with more reactional outbreaks, as the amount of bacillus and, subsequently of bacillary residues, is higher, rendering these individuals more susceptible to neural damage and possible sequelae. In leprosy the reactional state is the main cause of incapacities. Similar findings were observed in a study performed during the period of January 1981 and December 1983, showing more neural involvement in lepromatous and borderline patients (MB), and less on the tuberculoid cases $(\mathrm{PB}){ }^{21}$

Overall in the cases observed on this study, the higher the level of incapacity the worse the quality of life. Despite the fact that the therapeutic scheme can possibly cure, leprosy can cause reactions on the patients during the treatment and even after finishing it, when cases of neuritis might develop and, if the patient is not given specific orientation and treatment in time, it can lead to incapacities. ${ }^{28}$

The presence of physical incapacities seriously compromise the quality of life of the patient. ${ }^{24,29}$ According to the International Classification of Impediments, Deficiencies and Incapacities, incapacity is a disadvantage that an individual has, resulting from impediment or deficiency, which limits or makes it impossible the performing of a role, being defined 
TABLE 8: Descriptive statistics with presentation of the average, median and standard deviation and comparison of the ratings of each domain and the global perception of the quality of life and health with the WHOQOL-

bref grading by level of physical incapacity of the 120 leprosy patients in Reactional Outbreak seen at the Sanitary Dermatology Reference Center of the Hospital Eduardo de Menezes of the Fundação Hospitalar do Estado de Minas Gerais - FHEMIG, Belo Horizonte, December 2007 to March 2008

\begin{tabular}{lllllll}
\hline $\begin{array}{l}\text { Physical } \\
\text { Incapacity } \\
\text { Level }\end{array}$ & Statistics & $\begin{array}{l}\text { Global Perception } \\
\text { QoL and Health }\end{array}$ & $\begin{array}{l}\text { Physical } \\
\text { Domain }\end{array}$ & $\begin{array}{l}\text { Psychological } \\
\text { Domain }\end{array}$ & $\begin{array}{l}\text { Social Relations } \\
\text { Domain }\end{array}$ & $\begin{array}{l}\text { Environment } \\
\text { Domain }\end{array}$ \\
\hline \multirow{4}{*}{0} & Average & 59,2 & 65,8 & 68,2 & 70,2 & 57,7 \\
& Median & 62,5 & 67,9 & 70,8 & 66,7 & 59,4 \\
& Standard Deviation & 17,6 & 9,5 & 10,3 & 15,8 & 10,8 \\
& Minimum & 25,0 & 46,4 & 45,8 & 41,7 & 37,5 \\
& Maximum & 75,0 & 78,6 & 87,5 & 100,0 & 78,1 \\
& Average & 50,2 & 46,4 & 57,2 & 60,0 & 52,7 \\
1 & Median & 50,0 & 46,4 & 58,3 & 58,3 & 50,0 \\
& Standard Deviation & 14,2 & 13,5 & 13,5 & 14,6 & 9,8 \\
& Minimum & 12,5 & 21,4 & 12,5 & 16,7 & 15,6 \\
& Maximum & 75,0 & 92,9 & 83,3 & 100,0 & 78,1 \\
& Average & 44,6 & 41,2 & 55,5 & 60,4 & 50,4 \\
2 & Median & 37,5 & 39,3 & 54,2 & 58,3 & 50,0 \\
& Standard Deviation & 15,7 & 15,5 & 16,2 & 19,9 & 12,5 \\
& Minimum & 12,5 & 10,7 & 8,3 & 16,7 & 28,1 \\
P-value* & Maximum & 75,0 & 75,0 & 83,3 & 100,0 & 78,1 \\
& & 0,013 & 0,000 & 0,002 & 0,070 & 0,044 \\
\hline
\end{tabular}

*Kruskall-Wallis Test

as any restriction or loss of capacity to perform an activity within the normal moulds and limits for the human being. ${ }^{24}$

A study performed with the objective of describing the emotional reactions of leprosy patients with physical deformity under outpatient treatment reported that this population was nonconformist with their deformities, presenting with various emotional symptoms like: sadness and, at the same time anger, revolt, guilt, destruction and shame due to their horrible aspect; anguish related to the fear of facing others' looks, of the future, the mutilation and the disease, of being abandoned by the family, of rejection and solitude; worrying with the expectation in regards to the future; insecurity related to the loss of familiar and social interactions, as well as the feeling of futility, as the deformities limit working activities. ${ }^{30}$ In a way consonant with the above exposed, it can be observed that, from the patients studied, $85,9 \%$, reported presenting with negative feelings like bad mood, desperation, anxiety and depression.

The patients with reactional outbreaks under treatment, making use of PCT and corticosteroids, present with physical alterations like change of skin color (brown) and edema, which can be justified by the $50 \%$ of participants that reported being "more or less" satisfied with the physical appearance. 22
The evaluation of the Internal Consistency of the WHOQOL-bref, by means of application of the "Cronbach Alpha Coefficient" was performed in order to verify if the items are highly correlated with each other, as the evaluated attributes are, in theory, the same. This coefficient tests the correlation of the instrument items in each one of the domains as, the highest the alpha, the highest the homogeneity of the analysed items, an indication of the accuracy of the measure. ${ }^{16}$

In the present study the values of alpha were higher than 0,60 . This way, the WHOQOL-bref had an acceptable internal consistency for the facets and domains of this instrument, highly correlated with each other, indicating homogeneity of the items evaluated and evidenciating the quality and reliability of the instrument to evaluate the quality of life of patients with leprosy. This performance was similar to that described on the literature, as a recent study performed in Bangladesh with patients with leprosy and using the WHOQOL-bref, had the value of alpha of $0,83 .{ }^{12}$

\section{CONCLUSIONS}

The application of the proposed instrument for the evaluation of quality of life (WHOQOL-bref), showed evidence that leprosy causes damage to the daily 
life of the patients, generating suffering that goes beyond the pain and the malaise strictly linked to the physical damage, with great social and psychological impact.

The development of multidisciplinary actions aiming not only at the elimination, but also at the prevention of incapacities, stimulus to the adherence to the treatment and fight against the social stigma is thus necessary, in order to minimize the impact of the disease on the patients'life.

\section{REFERENCES}

1. Brasil. Ministério da Saúde. Secretaria de Políticas de Saúde. Departamento de Atenção Básica. Guia Para o Controle da Hanseníase. Cadernos da Atenção Básica $n^{0}$ 10. Série A: Normas e Manuais Técnicos $n^{0}{ }^{111}$. 1. ed. Brasília: Ministério da Saúde; 2002. 89 p.

2. Sampaio SAP, Rivitti EA. Dermatologia. 3 ed. São Paulo: Artes Médicas; 2007.

3. Araújo MG. Hanseníase no Brasil. Rev Soc Bras Med Trop. 2003;36:373-82.

4. Cunha AZS. Hanseníase: a história de um problema de Saúde Pública [dissertação]. Santa Cruz do Sul (RS): Universidade de Santa Cruz do Sul; 1997. 125 p.

5. Talhari S, Neves RG, Penna GO, Oliveira MLV. Dermatologia Tropical: Hanseníase. 4. ed. Manaus: Editora Tropical; 2006.

6. Singhi MK, Ghiya BC, Gupta D, Kachhawa D. Disability rates in leprosy. Indian J Dermatol Venereol Leprol. 2004;70:314-6.

7. Aquino DM, Caldas ALM, Silva AAM, Costa JML. Perfil dos pacientes com hanseníase em área hiperendêmica da Amazônia do Maranhão, Brasil. Rev Soc Bras Med Trop. 2003;36:57-64.

8. Feliciano KVO, Kovacs MH. Opiniões sobre a doença entre membros da rede social de pacientes de hanseníase no Recife. Rev Panam Salud Publica. 2007;1:112-8.

9. Silva DMGV, Vieira RM, Koschnik Z, Azevedo M, Souza SS. Qualidade de vida de pessoas com insuficiência renal crônica em tratamento hemodialítico. Rev Bras Enferm. 2002;55:562-7.

10. Martins BDL, Torres FN, Oliveira MLWDR. Impacto na qualidade de vida em pacientes com hanseníase: correlação do Dermatology Life Quality Index com diversas variáveis relacionadas à doença. An Bras Dermatol. 2008;83:39-43.

11. Seidl EMF, Zannon CMLC. Qualidade de vida e saúde: aspectos conceituais e metodológicos. Cad Saúde Pública. 2004;20:580-8.

12. Tsutsumi A, Izutsu T, Islam AM, Maksuda AN, Kato H, Wakai S. The quality of life, mental health, and peceived stigma of leprosy patients in Bangladesh. Soc Sci Med. 2007;64:2443-53

13. Saupe R, Broca GS. Indicadores de qualidade de vida como tendência atual de cuidado a pessoas em hemodiálise. Texto Contexto Enferm. 2004;13:100-6.

14. Fleck MPA, Louzada S, Xavier M, Chachamovich E, Vieira G, Santos H. Aplicação da versão em português do instrumento abreviado de avaliação da qualidade de vida "WHOQOL-bref". Rev Saúde Pública. 2000;34:178-83.

15. Michelone APC, Santos VLCG. Qualidade de vida de adultos com câncer colorretal com e sem ostomia. Rev Lat-Am Enfermagem. 2004;12:875-83.

16. Zanei SSV. Análise dos instrumentos de avaliação de qualidade de vida WHOQOL-bref e SF-36: confiabilidade, validade e concordância entre pacientes de Unidades de Terapia Intensiva e seus familiares [tese]. São Paulo (SP): Universidade de São Paulo; 2006. 189 p.

17. Soares JF, Siqueira AL. Introdução à Estatística Médica. 2 ed. Belo Horizonte: Coopmed; 2002.

18. Nunes JM. Ter Hanseniase: percepções das pessoas em tratamento [monografia]. Sobral (CE): Universidade Estadual Vale do Acarajú; 2004. 95 p.

19. Pinto VPT. Contexto real de vivência da Hanseníase: a imersão de estudantes da Faculdade de Medicina da Universidade Federal do Ceará-Sobral/CE. In: XIII Encontro de Extensão da UFC. Anais do XIII Encontro de Extensão da UFC; 20-22 Out. Fortaleza; 2004
20. Paschoal VD. Um sistema de cores na caracterização biopsicossocial do portador de hanseníase reacional [dissertação]. São José do Rio Preto (SP): Faculdade de Medicina de São José do Rio Preto; 1998. 129 p.

21. Corrêa CMJ, Ivo ML, Honer MR. Incapacidades em sujeitos com hanseníase em um centro de referência do Centro-Oeste Brasileiro entre 2000-2002. Hansen Int. 2006;31:21-8.

22. Mendes VO. Repercussões da Hanseníase no Cotidiano de Pessoas e de seus Familiares [monografia]. Sobral (CE): Universidade Estadual Vale do Acarajú; 2004. $53 \mathrm{p}$.

23. Yamanouchi AA, Caron CR, Shiwaku DT, Soares FB, Nicolodelli MA, Adur RC, et al. Hanseníase e sociedade: um problema sempre atual. An Bras Dermatol. 1993;68:396-404.

24. Monteiro MPA. Incapacidades físicas em pacientes com Hanseníase acompanhados pelas Equipes de Saúde da Família da Zona Urbana de Sobral - Ceará [monografia]. Sobral (CE): Universidade Estadual Vale do Acarajú; 2004. 86 p.

25. Pimentel MIF, Nery JAC, Borges E, Gonçalves RR, Sarno EN. 0 exame neurológico inicial na hanseníase multibacilar: correlação entre a presença de nervos afetados com incapacidades presentes no diagnóstico e com a ocorrência de neurites francas. An Bras Dermatol. 2003;78:561-8.

26. Andrade V, Pellegrini B. 0 que mudou na Hanseníase com a NOAS. Rio de Janeiro: Secretaria de Estado de Saúde do Rio de Janeiro e GT/ HANSEN/ CONASEMS; 2001. $80 \mathrm{p}$.

27. Duarte MTC, Ayres JA, Simonetti JP. Perfil socioeconômico e demográfico de portadores de Hanseníase atendidos em consulta de enfermagem. Rev Lat-Am Enfermagem. 2007;15:774-9.

28. Opromolla DVA. Noções de Hanseonologia. 2 ed. Bauru: Centro de Estudos Dr. Reynaldo Quagliato; 2000.

29. Brasil. Ministério da Saúde. Secretaria de Políticas de Saúde. Departamento de Gestão de Políticas Estratégicas. Área Técnica de Dermatologia Sanitária. Guia para implantar/implementar as atividades de controle da hanseníase nos planos estaduais e municipais de saúde. Brasília: Ministério da Saúde; 1999. 28 p.

30. Oliveira MHP. Reações emocionais dos hansenianos portadores de deformidade física. Hansen Int. 1990;15:16-23.

\footnotetext{
MAILING ADDRESS / ENDEREÇO PARA CORRESPONDÊNCIA :

Marina Dias Costa

Rua Presidente Arthur Bernardes, 655 - Centro 37130-000 Alfenas, MG, Brazil

Phone.: +55 (35) 3291-2375

E-mail:marinaderm@botmail.com
}

How to cite this article/Como citar este artigo: Costa MD, Terra FS, Costa RD, Lyon S, Dias-Costa AMD, Antunes CMF. Assessment of quality of life of patients with leprosy reactional states treated in a dermatology reference center. An Bras Dermatol. 2012;87(1):26-35. 